\title{
Occurrence and significance of phytanyl arenes across the Permian-Triassic boundary interval
}

\author{
H. Grotheer ${ }^{\mathrm{a}}$, P. Le Métayer ${ }^{\mathrm{a}}$, M.J. Piggott ${ }^{\mathrm{b}}$, E.J. Lindeboom ${ }^{\mathrm{b}}$, A.I. Holman ${ }^{\mathrm{a}}$, R.J. Twitchett ${ }^{\mathrm{c}}$, K. Grice ${ }^{\mathrm{a}, *}$ \\ ${ }^{a}$ WA Organic and Isotope Geochemistry Centre, The Institute for Geoscience Research, Department of Chemistry, Curtin University, GPO Box U1987, Perth, WA 6845, Australia \\ ${ }^{\mathrm{b}}$ School of Chemistry and Biochemistry, University of Western Australia, Perth, WA 6009, Australia \\ ${ }^{\mathrm{c}}$ Department of Earth Sciences, Natural History Museum, Cromwell Rd., London SW7 5BD, United Kingdom
}

\section{A R T I C L E I N F O}

\section{Article history:}

Received 18 July 2016

Received in revised form 30 November 2016

Accepted 6 December 2016

Available online 23 December 2016

\section{Keywords:}

Permian-Triassic boundary

Biomarker

Mass extinction

Phytanyl benzene

Phytanyl toluene

Phytanyl naphthalene

\begin{abstract}
A B S T R A C T
Phytanyl benzene and phytanyl toluene occur in mudstones from several key Permian-Triassic Boundary (PTB) sections from mid-northern palaeolatitudes (Spitsbergen and Eastern Greenland), as well as mid-southern palaeolatitudes (Western Australia). The occurrence of these compounds through the different PTB sections is related to the occurrence of the previously identified $C_{33} n$-alkyl cyclohexane, suggesting their parent organism shared a similar unique ecological niche and was associated with the extinction horizon. Further, the lack of these compounds in the carbonate-dominated palaeoequatorial, Global Stratotype Section and Point (GSSP), Meishan-1 (South China) section possibly points to their source being temperature and climate controlled.
\end{abstract}

(c) 2016 Elsevier Ltd. All rights reserved.

\section{Introduction}

Long chain alkyl benzenes and alkyl toluenes are common constituents of crude oils and sedimentary organic matter (Albaigés et al., 1986; Williams et al., 1988; Radke and Willsch, 1993; Sinninghe Damsté et al., 1993; Hartgers et al., 1994). Homologous series of long chain alkyl benzenes have been reported in a number of different geological samples (e.g. Solli et al., 1980; Gallegos, 1981). The first tentative assignments were later confirmed by co-injection with authentic standards (e.g. Albaigés et al., 1986). The presence of alkyl benzenes with isoprenoid side chains is also well documented (Schaeflé et al., 1977; Summons and Powell, 1987; Sinninghe Damsté et al., 1988). However, the origin of most of these biomarkers is not well established and various formation pathways have been proposed. For example, alkyl benzenes and ring-methylated homologues may be formed either by direct biosynthesis by specific communities of archaea (Holzer et al., 1979; Sinninghe Damsté et al., 1988, 1993), diagenetic conversion of isoprenoid quinones (Connan et al., 1986; Sinninghe Damsté et al., 1988), cyclisation and aromatisation of fatty acids and alcohols (Dong et al., 1993; Ellis et al., 1995, 1999) or by diagenetic degradation (Killops et al., 2014), for instance of specific carotenoids such as isorenieratene (Summons and Powell, 1987). Despite

\footnotetext{
* Corresponding author.

E-mail address: K.Grice@curtin.edu.au (K. Grice).
}

their ambiguous origin, the differences in their distributions (e.g. Connan et al., 1986; Sinninghe Damsté et al., 1993) indicate that alkyl benzenes, like other unambiguous biomarkers, can be characteristic of specific microbial communities or associated with particular depositional conditions (Holzer et al., 1979; Connan et al., 1986; Sinninghe Damsté et al., 1993; Killops et al., 2014).

Here we report the appearance (Scheme 1) of 3,7,11,15-tetrame thylhexadecylbenzene (phytanyl benzene, 4a) and 1-methyl-3-(3,7,1 1,15-tetramethylhexadecyl)benzene (phytanyl toluene, $\mathbf{4 b}$ ) in mudstones from three sections that span the Permian/Triassic Boundary (PTB): the Hovea-3 core (northern onshore Perth Basin, Western Australia), the Fiskegrav section (Schuchert-Dal, Jameson Land, East Greenland) and Lusitaniadalen (Spitsbergen, Svalbard). The first unambiguous assignment of phytanyl benzene and phytanyl toluene in sediments and oils is credited to Sinninghe Damsté et al. (1988). These biomarkers were subsequently reported in only a few case studies, including a number of evaporitic systems (Sinninghe Damsté et al., 1988, 1993; Grimalt et al., 1991). It has been proposed that they are related to specific halophilic archaea, based in particular on correlation between the relative concentration of these biomarkers and the chroman ratios (as defined by Sinninghe Damsté et al., 1993).

Globally, rocks spanning the Permian-Triassic interval have received considerable attention because they record the Late Permian extinction event, the most severe crisis of the Phanerozoic, and the subsequent Early Triassic recovery (e.g. Benton and Twitchett, 2003; Grice et al., 2005a; Foster and Twitchett, 2014). Biomarkers 
<smiles>CC(=CCO)CCCC(C)CCCC(C)CCCC(C)C</smiles>
1<smiles>CC(=CC=O)CCCC(C)CCCC(C)CCCC(C)C</smiles>

2<smiles>CC(=C[C@@H](O)Br)CCCC(C)CCCC(C)CCCC(C)C</smiles>

3

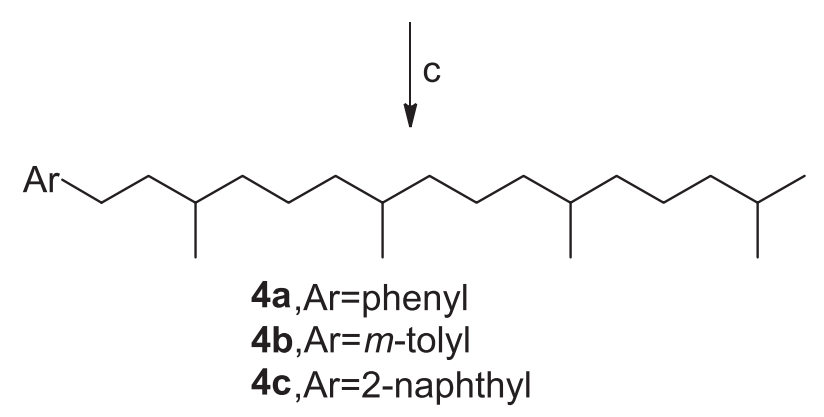

Scheme 1. Synthesis of phytanyl arene standards. Reagents, conditions and yields: (a) $\mathrm{MnO}_{2}$, hexanes, $81 \%$; (b) $\mathrm{ArMgBr}, \mathrm{Et}_{2} \mathrm{O}$, then $10 \% \mathrm{H}_{2} \mathrm{SO}_{4}$ (3a, $\mathrm{Ar}=$ phenyl $-80 \%$, 3b, $\mathrm{Ar}=m$-tolyl $-76 \%, 3 \mathbf{c}, \mathrm{Ar}=2$-naphthyl - 69\%); (c) $\mathrm{H}_{2}, \mathrm{Pd} / \mathrm{C}, \mathrm{AcOH}, \mathrm{EtOH}(\mathbf{4 a}-$ $89 \%, \mathbf{4 b}-60 \%, \mathbf{4 c}-59 \%)$.

such as those related to isorenieratene have provided critical palaeoenvironmental information, indicating the presence of photic zone euxinic conditions in the extinction aftermath (Grice et al., 2005a; Fenton et al., 2007; Hays et al., 2007; Nabbefeld et al., $2010 b)$. The biomarker $n$-heptacosylcyclohexane $\left(C_{33} n\right.$-alkyl cyclohexane; $\left.\mathrm{C}_{33} n-\mathrm{ACH}\right)$ (Mclldowie and Alexander, 2005; Grice et al., 2005b; Nabbefeld et al., 2010b) may also have stratigraphic value in providing a proxy for the mass extinction horizon. $\mathrm{C}_{33} \mathrm{n}-\mathrm{ACH}$ has only been reported from early Triassic source rocks and related oils in the northern Perth Basin (Western Australia) and PTB sections in East Greenland (Grice et al., 2005b) and Spitsbergen (Nabbefeld et al., 2010b). It was postulated that its appearance is related to specific environmental conditions during and following the major ecological crisis, which supported a phytoplankton community uniquely adapted to these conditions (Grice et al., 2005b; Nabbefeld et al., 2010b). The aims of this study were to synthesise 3,7,11,15-tetrame thylhexadecylbenzene (4a), 1-methyl-3-(3,7,11,15-tetramethylhexa decyl)benzene (4b) and 2-(3,7,11,15-tetramethylhexadecyl)naphtha lene (4c; Scheme 1) and to use them as standards to confirm their presence in or absence from PTB sections and thereby their significance (temperature and climate) in sections around the world.

\section{Material and methods}

\subsection{Samples}

Samples containing phytanyl benzene and phytanyl toluene came from three PTB sections in the Perth Basin (Western Aus- tralia), Fiskegrav (Jameson Land, East Greenland) and Lusitaniadalen (central Spitsbergen, Svalbard). The shallow marine lithofacies of the three sections are broadly similar, recording local expressions of the latest Permian marine transgression and a transition from well-bioturbated fine sandstones and siltstones of Changhsingian age to finer, deep water, and more laminated, less bioturbated mudstones with occasional thin, distal tempestites around the PTB.

\subsubsection{Hovea-3 core (Perth Basin, Western Australia)}

The core was drilled in the northern Perth Basin through the source rocks of the organic-rich Hovea Member (Thomas et al., 2004). The mid-southern palaeolatitude (Fig. 1) Hovea Member was deposited in a marine shelf environment, with a lower 'Inertinitic Interval' of bioturbated sandstones and mudstones, and an upper 'Sapropelic Interval' of laminated mudstones, including oilprone source rocks (Thomas et al., 2004). The abrupt facies change at the boundary between these two intervals (at a depth of $1980.95 \mathrm{~m}$ ) implies the presence of a hiatus, due to nondeposition during the transgression. A major palynological change occurs at this surface, which Thomas et al. (2004) used to define the local PTB in the absence of conodonts. In more complete sections elsewhere, similar palynological changes record the extinction event, which occurred prior to the PTB (e.g. Looy et al., 2001), but due to the condensed nature of this section the extinction and PTB are indistinguishable. The Early Triassic bivalve Claraia first appears just $20 \mathrm{~cm}$ above this horizon, which provides additional evidence that the section is the most condensed of the three studied. Forty-five samples from the core were studied, spanning both the lower inertinitic and upper sapropelic intervals. The maturity of the sampled section is relatively low, with vitrinite reflectance $\left(R_{\mathrm{e}}\right)$ values of $0.68 \%$ or lower (Dawson et al., 2005) for samples from the uppermost Permian. The methyl phenanthrene maturity index (MPI-1) ranges between 0.47 and 0.96 (Grice et al., 2007), with the highest values recorded for the Lower Triassic. The lack of coal and vitrinite in the early Triassic likely influenced the high MPI-1 values (Cassani et al., 1988) and the low maturity values reported for the Upper Permian can be assumed to span the entire studied section.

\subsubsection{Fiskegrav section (Jameson Land, Eastern Greenland)}

The mid-northern palaeolatitude (Fig. 1) Eastern Greenland PTB section was described by Twitchett et al. (2001) and comprises ca. $40 \mathrm{~m}$ of the uppermost Schuchert Dal Formation and overlying lowermost Wordie Creek Formation. The rocks comprise mudstones and siltstones deposited in a shallow marine embayment and contain a marine fauna and flora, as well as terrestrial spores and pollen (Looy et al., 2001). Due to the abundance of fish in the Wordie Creek Formation, the location is known as Fiskegrav (Stemmerik et al., 2001). Eleven samples from this section were analysed here, spanning the Upper Permian and Lower Triassic.

The PTB is defined by the first appearance of Hindeodus parvus in the Meishan-1 section of South China (Yin et al., 2001). Locally at Fiskegrav, $H$. parvus first appears ca. $23.5 \mathrm{~m}$ above the base of the Wordie Creek Formation (Twitchett et al., 2001). However, as noted by Twitchett et al. (2001), it is likely that the actual PTB horizon is lower in the Wordie Creek Formation because the bivalve Claraia, which indicates basal Triassic strata elsewhere, occurs ca. $10 \mathrm{~m}$ below the appearance of $H$. parvus, and the intervening rocks have not been sampled for conodonts. The local expression of the late Permian extinction event is recorded in the uppermost part of the underlying Schuchert Dal Formation and has been identified from the disappearance of bioturbation, changes in the acritarch record and the disappearance of Permian macro- and microfossils (Looy et al., 2001; Twitchett et al., 2001). These changes all occur within a marine transgression, but notably the facies change is 


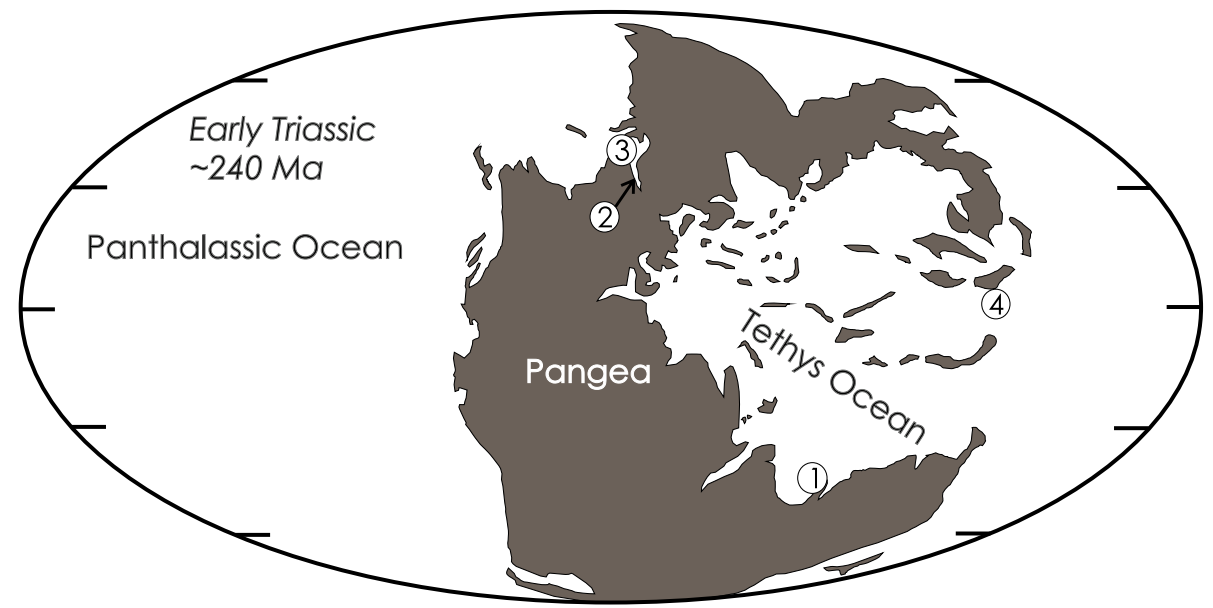

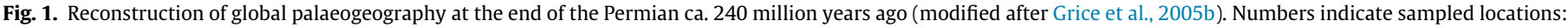
1, Hovea-3, Perth Basin, Western Australia; 2, Fishgrav, Jameson Land, East Greenland; 3, Lusitaniadalen, Spitsbergen, Svalbard; 4, Meishan, South China.

not as sharp as in the Hovea-3 core, with bioturbation disappearing over ca. $0.5 \mathrm{~m}$.

MPI-1 values for the samples ranged between very immature (0.07) for the Schuchert Dal Formation up to the onset of oil generation (0.52) for the Wordie Creek Formation, equating to a calculated vitrinite reflectance $\left(R_{\mathrm{c}}\right)$ of $0.44-0.71 \%$ (Nabbefeld et al., 2010a). As for the Hovea-3 core the MPI-1 values in the Lower Triassic (lowermost Wordie Creek Formation) possibly overestimate the maturity due to the absence of coal and vitrinite. The colour and exceptional preservation of palynomorphs (Looy et al., 2001) and the very low colour alteration index $(\mathrm{CAI}=1)$ of Wordie Creek Formation conodonts indicate unequivocally that the entire section is immature.

\subsubsection{Vikinghøgda section (Lusitaniadalen, Spitsbergen (Svalbard))}

The site exposed at Lusitaniadalen, Spitsbergen (Svalbard) records shallow marine, mid-palaeolatitude deposition at a site a few degrees north of Fiskegrav (Fig. 1), and was described by Mørk et al. (1999) and Nabbefeld et al. (2010b). The studied samples came from the lower ca. $12 \mathrm{~m}$ of the Deltadalen Member of the Vikinghøgda Formation. This interval was described in detail by Nabbefeld et al. (2010b) and records a transition from glauconitic, bioturbated fine-medium sandstones to predominantly laminated, dark grey mudstones, followed by the return of small burrows and benthic invertebrates in the upper part (Nabbefeld et al., 2010b). The latter authors followed the approach of Twitchett et al. (2001) and identified the horizon at which Permian marine ecosystems collapsed as the last occurrence of abundant, high diversity of large Permian trace fossils, just before the top of the glauconitic sandstones, $1.53 \mathrm{~m}$ above the base of the Vikinghøgda Formation. Marine ecosystem collapse occurred after the onset of a marine transgression and the first evidence of anoxia (Nabbefeld et al., 2010b).

The exact location of the PTB at the Lusitaniadalen site is unclear since the conodont $H$. parvus does not occur in the area. Mørk et al. (1999) originally placed the PTB at the base of the Vikinghøgda Formation while, more recently, Hounslow et al. (2008) shifted the boundary $12 \mathrm{~m}$ above, based on magnetostratigraphic data, whereas Nakrem et al. (2008) placed the PTB in-between on the basis of conodonts. The sediments are slightly more mature than the other sections, with MPI-1 values ranging from $0.46-0.69$ ( $R_{\mathrm{c}}$ 0.68-0.82\%; Nabbefeld et al., 2010a).

\subsection{Extraction and fractionation}

Crushed sediment (ca. $80 \mathrm{~g}$ ) was extracted using automated accelerated solvent extraction (DIONEX ASE 200) with dichloro- methane $(\mathrm{DCM}) / \mathrm{MeOH}(9: 1, \mathrm{v} / \mathrm{v})$ at $100{ }^{\circ} \mathrm{C}$ and 1000 psi. The extraction procedure was repeated $3 \times$. The extract was fractionated via silica gel column chromatography using $n$-pentane for eluting aliphatic hydrocarbons, 30\% DCM/pentane (v/v) for aromatic hydrocarbons and $50 \% \mathrm{DCM} / \mathrm{MeOH}(\mathrm{v} / \mathrm{v})$ for the polar compounds. Solvent was carefully removed under $\mathrm{N}_{2}$.

\subsection{Gas chromatography-mass spectrometry (GC-MS)}

GC-MS was carried out with a HP 6890 gas chromatograph coupled to a HP 5973 mass spectrometer operating in electron impact ionization mode $(70 \mathrm{eV})$. Separation was achieved using a $60 \mathrm{~m} \times 0.25 \mathrm{~mm}$ i.d. WCOT fused silica column coated with $0.25 \mu \mathrm{m}$ film (DB-5, J\&W Scientific) and He as carrier gas at $1 \mathrm{ml} /$ min. Samples were dissolved in $n$-hexane and $1 \mu$ l was injected using a HP 6890 auto-sampler. The GC oven temperature programme was $40-325^{\circ} \mathrm{C}$ (at $3{ }^{\circ} \mathrm{C} / \mathrm{min}$; final temperature held $45 \mathrm{~min}$ ). Chromatographic peaks were integrated using the HP ChemStation data analysis program.

\subsection{Synthesis of phytanyl benzene and phytanyl toluene}

Although we considered a combinatorial synthesis for the three target compounds along the lines of those described previously (Greenwood et al., 2009; Lengkeek et al., 2010), in this case traditional synthesis was not onerous, due to the limited number of reactions entailed. Thus, the phytanyl arene standards $\mathbf{4 a - c}$ were prepared in three steps, as depicted in Scheme 1. Oxidation of phytol (1; Aldrich, mixture of isomers) with $\mathrm{MnO}_{2}$ gave phytenal (2) as a ca. 2:1 mixture of $E$ and $Z$ isomers, respectively (Kulkarni et al., 1988; Knierzinger et al., 1990). Addition of aryl Grignard reagents to $\mathbf{2}$ provided the secondary allylic alcohols $\mathbf{3 a - c}$. Similar reactions have been used in the synthesis of $\alpha$-tocopherol (Hübscher and Barner, 1990) and vitamin K epoxide analogues (Ryall et al., 1990). Hydrogenation/hydrogenolysis (Lengkeek et al., 2010) of 3a-c afforded the target hydrocarbons 4a-c.

Phytanyl benzene (4a) and ring-methylated congeners have been synthesised previously via a Barbier reaction of aryl bromides with phytal, prepared in four steps from phytol (1), followed by reductive deoxygenation with triethylsilane/trifluoroacetic acid (Sinninghe Damsté et al., 1988); the approach used here is more succinct.

\subsubsection{General experimental details}

${ }^{1} \mathrm{H}$ NMR spectra were acquired in $\mathrm{CDCl}_{3}$ at $25^{\circ} \mathrm{C}$ with a Varian Inova $300\left({ }^{1} \mathrm{H}, 300 \mathrm{MHz},{ }^{13} \mathrm{C} 75 \mathrm{MHz}\right)$ spectrometer. Rapid silica fil- 
tration (RSF) refers to chromatography on a short column of silica gel in a sintered glass funnel, in which the eluent is sucked through the column under vacuum. Other general experimental details are as described by Gandy and Piggott (2008).

Phytal (2; Kulkarni et al., 1988; Knierzinger et al., 1990). $\mathrm{MnO}_{2}$ $(29 \mathrm{~g}, 0.33 \mathrm{~mol})$ was added to a solution of phytol $(\mathbf{1} ; 5.00 \mathrm{~g}$, $16.7 \mathrm{mmol}$, mixture of isomers) in $n$-hexane $(350 \mathrm{ml})$ under $\mathrm{Ar}$ and the suspension stirred for $3 \mathrm{~h}$. The reaction mixture was vacuum filtered and the filter cake washed with $n$-hexane $(2 \times 100 \mathrm{ml})$. The filtrate was evaporated and the residue subjected to RSF. Elution with $n$-hexane provided 2 as a colourless oil $(4.0 \mathrm{~g}$, 81\%). ${ }^{1} \mathrm{H}$ NMR (300 MHz): $\delta$ 9.94-10.00 (1H, m, CHO) 5.86-5.89 $(1 \mathrm{H}, \mathrm{m},=\mathrm{CH}) 2.15(3 \mathrm{H}, \mathrm{br} \mathrm{s}), 1.05-1.54(21 \mathrm{H}, \mathrm{m}), 0.83-0.87(12$ $\mathrm{H}, \mathrm{m})$. The ${ }^{1} \mathrm{H}$ NMR data are slightly different from those reported by Upadhyay et al. (2014).

2.4.1.1. 3,7,11,15-Tetramethyl-1-phenylhexadec-2-en-1-ol (3a). Bromobenzene $(450 \mu \mathrm{l}, 4.3 \mathrm{mmol})$ was added dropwise to a suspension of $\mathrm{Mg}$ (207 mg, $8.52 \mathrm{mmol})$ in anhydrous $\mathrm{Et}_{2} \mathrm{O}(2 \mathrm{ml})$ under $\mathrm{Ar}$ and the reaction mixture heated under reflux for $30 \mathrm{~min}$. The solution of the Grignard reagent was cooled to $0{ }^{\circ} \mathrm{C}$ and a solution of phytal (2; $940 \mathrm{mg}, 3.2 \mathrm{mmol})$ in $\mathrm{Et}_{2} \mathrm{O}(2 \mathrm{ml})$ was added dropwise. The reaction mixture was allowed to warm to room temperature and stirred for another $30 \mathrm{~min}$, then cooled to $0{ }^{\circ} \mathrm{C}$, quenched with $10 \% \mathrm{H}_{2} \mathrm{SO}_{4}(10 \mathrm{ml})$ and extracted with $\mathrm{Et}_{2} \mathrm{O}(3 \times 30 \mathrm{~mL})$. The extract was dried $\left(\mathrm{MgSO}_{4}\right)$ and the solvent evaporated, and the residue subjected to RSF. Elution with 5\% EtOAc/hexane provided 3a as a colourless oil (950 mg, 80\%). IR $\left(\mathrm{v}, \mathrm{cm}^{-1}\right)$ : 3443, br $(\mathrm{OH})$. ${ }^{1} \mathrm{H}$ NMR $(300 \mathrm{MHz}): \delta$ 7.24-7.42 (5H, m, Ar), 5.41-5.51 $(2 \mathrm{H}, \mathrm{m}$, vinylic/benzylic), 1.75-1.80 (3H, m), 1.04-1.56 $(22 \mathrm{H}, \mathrm{m}), 0.84-$ $0.90(12 \mathrm{H}, \mathrm{m}) ;{ }^{13} \mathrm{C}$ NMR $(75 \mathrm{MHz}): \delta 144.4,139.3,128.57,128.56$, $128.0,127.41,127.36,127.33,126.1,126.0,70.8,70.5,40.03$, $40.00,39.5,37.56,37.53,37.46,37.43,36.9,36.8,32.9,32.84$, $32.81,32.79,32.77,32.75,28.1,25.8,25.25,25.23,25.0,24.6$, 23.6, 22.9, 22.8, 19.9, 19.8, 16.8 .

2.4.1.2. 3,7,11,15-Tetramethyl-1-m-tolylhexadec-2-en-1-ol (3b). Prepared as described above from $m$-bromotoluene $(520 \mu \mathrm{l}$, $4.3 \mathrm{mmol})$, giving $\mathbf{3 b}$ as a colourless oil $(1.00 \mathrm{~g}, 76 \%)$. IR $(\mathrm{V}$, $\left.\mathrm{cm}^{-1}\right): 3448$, br $(\mathrm{OH}) .{ }^{1} \mathrm{H}$ NMR $(300 \mathrm{MHz}): \delta 7.11-7.31(4 \mathrm{H}, \mathrm{m}$, Ar), $5.48(2 \mathrm{H}, \mathrm{m}$, vinylic/benzylic), $2.41(3 \mathrm{H}, \mathrm{s}) 1.84(3 \mathrm{H}, \mathrm{m})$, 1.11-1.65 $(22 \mathrm{H}, \mathrm{m}), 0.88-0.93(12 \mathrm{H}, \mathrm{m}) ;{ }^{13} \mathrm{C}$ NMR $(75 \mathrm{MHz}): \delta$ $144.4,139.3,138.2,128.53,128.52,128.21,128.16,127.4,126.8$, 126.7, 123.13, 123.08, 70.8, 70.6, 40.1, 39.5, 37.6, 37.5, 36.9, 36.8, $32.9,32.84,32.82,28.1,25.0,24.62,24.61,23.7,22.9,22.8,21.9$, $21.65,21.63,19.9,19.8,16.8$.

2.4.1.3. 3,7,11,15-Tetramethyl-1-(naphthalen-2-yl)hexadec-2-en-1-ol (3c). Prepared as described above from 2-bromonaphthalene (880 mg, $4.3 \mathrm{mmol})$, giving $3 \mathrm{c}$ as a colourless oil $(990 \mathrm{mg}, 69 \%)$ IR $\left(v, \mathrm{~cm}^{-1}\right): 3458, \operatorname{br}(\mathrm{OH}) .{ }^{1} \mathrm{H}$ NMR $(300 \mathrm{MHz}): \delta 7.82-7.85(4 \mathrm{H}$, $\mathrm{m}, \mathrm{Ar}), 7.45-7.53(3 \mathrm{H}, \mathrm{m}, \mathrm{Ar}), 5.48-5.67(2 \mathrm{H}, \mathrm{m}$, vinylic/benzylic), $1.78-1.85$ (3H, m), $1.07-1.58(22 \mathrm{H}, \mathrm{m}), 0.83-0.89(12 \mathrm{H}, \mathrm{m}) ;{ }^{13} \mathrm{C}$ NMR $(75 \mathrm{MHz}): \delta 141.8,139.7,133.5,132.9,128.4,128.11$, $128.10,127.8,127.2,126.2,125.8,124.6,124.3,71.0,70.7,40.07$, $40.04,39.5,37.5,37.4,36.8,32.9,32.8,28.1,25.2,25.0,24.6$, 23.7, 22.9, 22.8, 19.9, 19.8, 16.9 .

2.4.1.4. 3,7,11,15-Tetramethylhexadecylbenzene (phytanyl benzene; 4a). A suspension of $3 a(810 \mathrm{mg}, 2.2 \mathrm{mmol})$ and $10 \% \mathrm{Pd} / \mathrm{C}(0.24 \mathrm{~g})$ in 1:9 AcOH/EtOH $(50 \mathrm{ml})$ was stirred overnight under a balloon of $\mathrm{H}_{2}$. The reaction mixture was vacuum filtered through a pad of Celite and rinsed with EtOH $(100 \mathrm{ml})$. The filtrate was evaporated to give $4 \mathbf{a}$ as a colourless oil (694 mg, 89\%). ${ }^{1} \mathrm{H}$ NMR $(300 \mathrm{MHz})$ : $\delta$ 7.14-7.31 (5H, m, Ar), 2.56-2.69 (2H, m), 1.08-1.75 (25H, m), $0.93(2 \mathrm{H}, \mathrm{m}), 0.86(12 \mathrm{H}, \mathrm{m}) ;{ }^{13} \mathrm{C}$ NMR $(75 \mathrm{MHz}): \delta 143.4(\mathrm{Ar})$,
$128.5(\mathrm{ArH}), 128.4(\mathrm{ArH}), 125.7(\mathrm{ArH}), 39.5,39.2,39.1,37.60$, $37.55,37.44,37.41,37.37,33.7,32.94,32.92,32.7,28.1,25.0$, 24.6, 24.5, 22.9, 22.8, 19.89, 19.85, 19.81, 19.75 .

2.4.1.5. 1-Methyl-3-(3,7,11,15-tetramethylhexadecyl)benzene (mphytanyl toluene; $\mathbf{4 b}$ ). Hydrogenation/hydrogenolysis of $\mathbf{3 b}$ $(1.00 \mathrm{~g}, 2.57 \mathrm{mmol})$ as described for $\mathbf{3 a}$ provided $\mathbf{4 b}$ as a colourless oil (582 mg, 60\%). ${ }^{1} \mathrm{H}$ NMR (300 MHz): $\delta 6.98-7.20(4 \mathrm{H}, \mathrm{m}), 2.52-$ $2.63(2 \mathrm{H}, \mathrm{m}), 2.34(3 \mathrm{H}, \mathrm{s}) 1.09-1.80(25 \mathrm{H}, \mathrm{m}), 0.96(2 \mathrm{H}, \mathrm{d}), 0.86$ $(12 \mathrm{H}, \mathrm{t}) ;{ }^{13} \mathrm{C}$ NMR $(75 \mathrm{MHz}): \delta 143.3,143.2,138.0,129.32$, 129.26, 128.4, 128.3, 126.5, 126.4, 125.5, 125.4, 40.1, 39.5, 38.7, $37.6,37.5,37.43,37.41,37.37,33.6,32.94,32.89,32.7,30.1,28.1$, $25.0,24.63,24.61,24.5,23.5,22.9,22.8,21.55,21.54,19.89$, $19.88,19.81,19.76,16.3$.

2.4.1.6. 2-(3,7,11,15-Tetramethylhexadecyl)naphthalene (phytanyl naphthalene) (4c). Hydrogenation/hydrogenolysis of $3 c$ (990 mg, $2.3 \mathrm{mmol}$ ) as described for $\mathbf{3 a}$ provided $\mathbf{4 c}$ as a colourless oil (562 mg, 59\%). ${ }^{1} \mathrm{H}$ NMR (300 MHz): $\delta 7.33-7.86$ (7H, m), 2.77$2.80(2 \mathrm{H}, \mathrm{m}), 1.10-1.56(25 \mathrm{H}, \mathrm{m}), 0.97(2 \mathrm{H}, \mathrm{d}, J=\mathrm{Hz}), 0.87(12 \mathrm{H}$, $\mathrm{t}, J=\mathrm{Hz}) ;{ }^{13} \mathrm{C}$ NMR $(75 \mathrm{MHz}): \delta 140.9,140.8,133.86,133.84$, 132.08, 132.06, 128.1, 128.0, 127.9, 127.8, 127.61, 127.56, 127.53, $127.51,127.49,126.36,126.35,126.30,126.24,126.04,126.00$, $125.97,125.20,125.12,40.0,39.6,39.1,39.0,38.8,37.6,37.58$, $37.52,37.48,37.43,33.8,33.97,32.96,32.72,32.71,30.4,28.1$, 25.00, 24.98, 24.67, 24.64, 24.57, 24.56, 23.6, 22.9, 22.8, 19.97, $19.94,19.91,19.88,19.81,16.32$.

\section{Results and discussion}

\subsection{Identification}

A striking feature of almost all 'post-extinction' samples is the presence of phytanyl toluene (4b; Fig. $2 \mathrm{~A}-\mathrm{C}$ ) in the aromatic fraction. It is the major component of samples from Greenland, whereas samples from Spitsbergen and Hovea- 3 are dominated by phenanthrene and methylated phenanthrene analogues. The identification is based on comparison with mass spectra and relative retention time described by Sinninghe Damsté et al. (1988) and with our authentic standard. The mass spectrum of $\mathbf{4 b}$ displays $\mathrm{M}^{+}$at $m / z 372\left(\mathrm{C}_{27} \mathrm{H}_{48}\right)$ and a base peak at $m / z 106$ resulting from $\gamma$-hydrogen transfer and a dimethylbenzene moiety (Fig. 4b; Sinninghe Damsté et al., 1988). The $\mathrm{m} / \mathrm{z} 106 / \mathrm{m} / \mathrm{z} 105$ ratio is ca. 5 , as described by Sinninghe Damsté et al. (1988). The retention time relative to that of the homologous series of $n$-alkyl toluenes (Fig. 3D-F) is also in agreement with the retention behaviour reported by Sinninghe Damsté et al. (1988), with phytanyl toluene eluting just after $\mathrm{C}_{24^{-}}$and before $\mathrm{C}_{25} n$-alkyl toluene, confirming the isoprenoid phytanyl side chain (Fig. 3D-F). The identification was confirmed by co-injection of the synthesised standard.

Phytanyl benzene (4a), previously identified by Sinninghe Damsté et al. (1988), was also detected in most 'post-extinction' samples. It was assigned here from the summed chromatogram of $m / z 91+92$ (Fig. $3 \mathrm{~A}-\mathrm{C}$ ), with a base peak at $\mathrm{m} / z 92$ and $\mathrm{M}^{+}$at $m / z 358\left(\mathrm{C}_{26} \mathrm{H}_{46}\right.$; Fig. 4a). Again, the dominance of even $m / z 92$ over odd $m / z 91$ is suggestive of $\gamma$-hydrogen transfer and the presence of a benzene moiety. Relative retention time compared with the homologous $n$-alkyl benzene series confirms the isoprenoid phytanyl side chain. Phytanyl benzene also co-eluted with the synthesised standard.

Phytanyl naphthalene (4c) was detected in very low abundance in only five of the samples, so does not appear to be a useful biomarker associated with specific conditions during PTB intervals. The mass spectrum of the standard is shown in Fig. $4 \mathrm{c}$ and displays a base peak at $m / z 142$, with $\mathrm{M}^{+}$at $m / z 408\left(\mathrm{C}_{30} \mathrm{H}_{48}\right)$. 


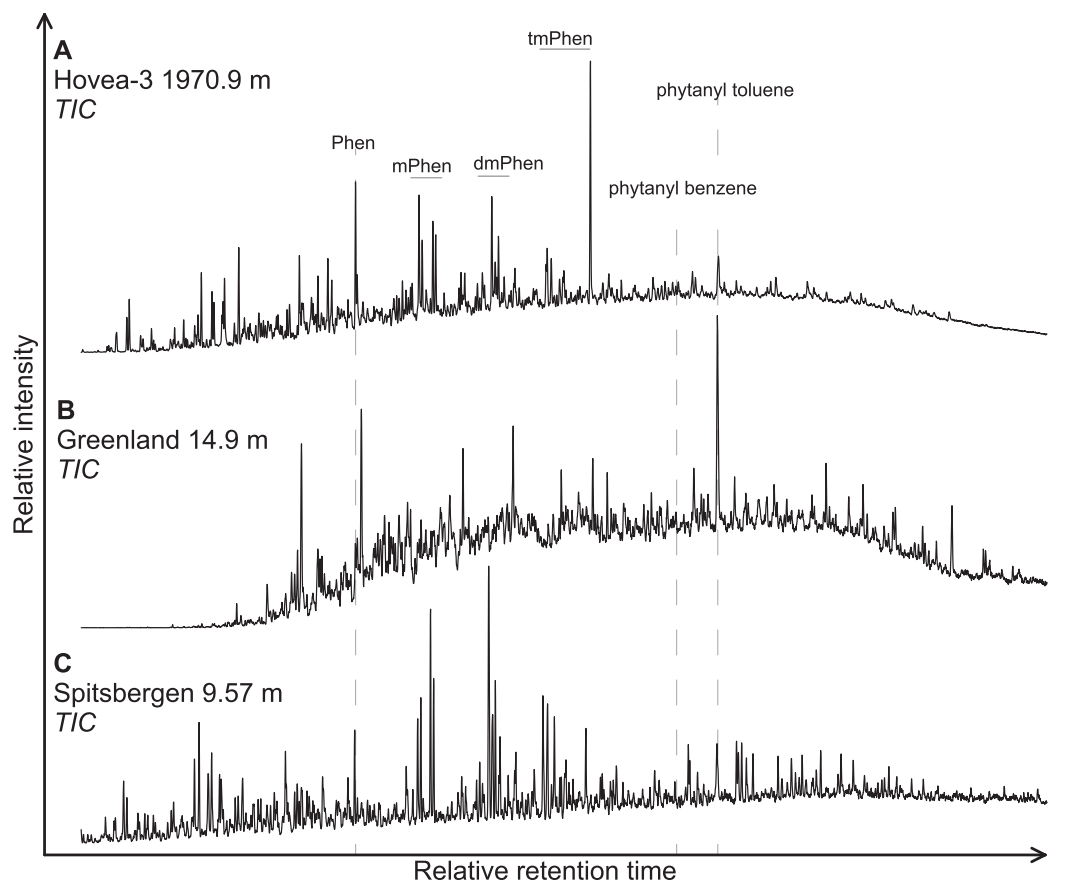

Fig. 2. Total ion chromatograms of aromatic fraction from the three sections from depths above the marine collapse.
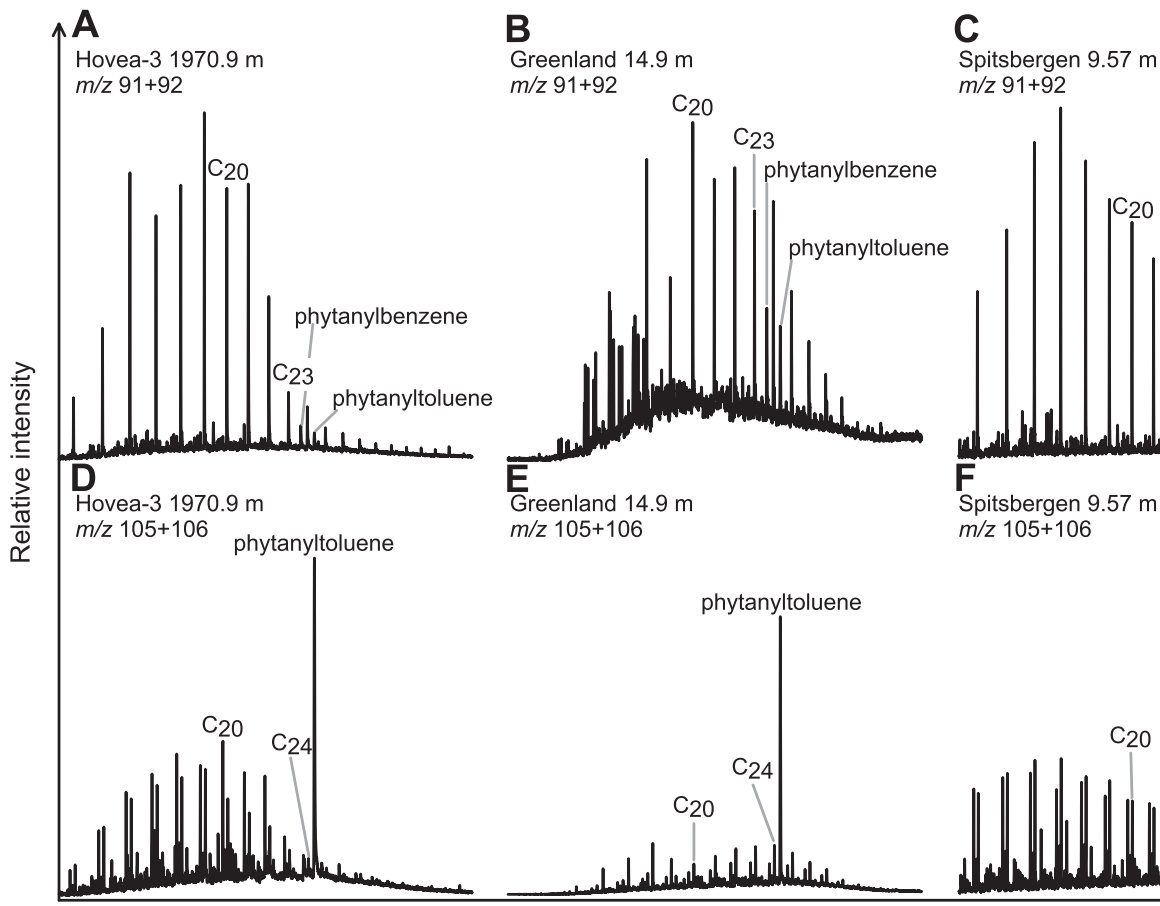
$\mathrm{m} / \mathrm{z} 91+92$ $m / z 91+92$

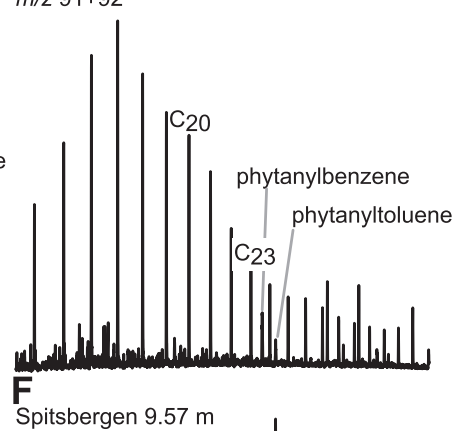
$\mathrm{m} / \mathrm{z} 105+106$

Relative retention time

Fig. 3. Summed ion chromatograms for alkyl benzenes $(m / z 91+92$, top) and alkyl toluenes $(m / z 105+106$, bottom) from the thre sections from depths above the marine collapse.

\subsection{Occurrence}

\subsubsection{Hovea-3 core}

The local PTB in the Hovea-3 core was identified at a depth of $1980.95 \mathrm{~m}$ by Thomas et al. (2004) but, due to a likely hiatus, the horizon also corresponds to the level at which the Permian fauna and spores/pollen disappear (Grice et al., 2005b). Phytanyl benzene and phytanyl toluene were present in samples from $1980.92 \mathrm{~m}$ and above, corresponding to the Lower Triassic upper Sapropelic Interval of the Hovea Member, but not in any Permian sample. Fig. 3A and D show the GC-MS extracted ion chromatograms of the alkyl benzenes $(\mathrm{m} / \mathrm{z} 91+92)$ and alkyl toluenes $(\mathrm{m} / \mathrm{z} 105$ +106 ) from the $1970.9 \mathrm{~m}$ sample, showing the occurrence of phytanyl benzene and phytanyl toluene. The far greater relative abundance of phytanyl toluene than phytanyl benzene is common to every sample in which these biomarkers appear. The phytanyl 

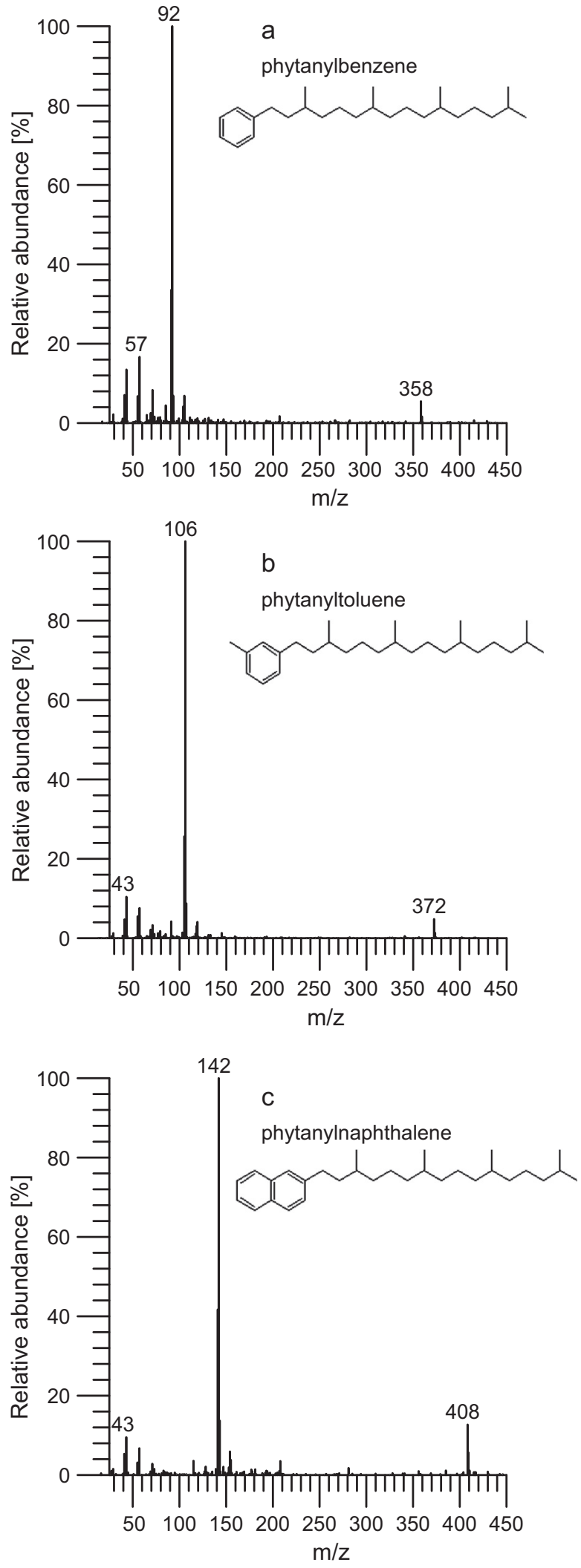

Fig. 4. Mass spectra (corrected for background) of synthetic (a) 3,7,11,15-tetramethylhexadecylbenzene (phytanyl benzene, 4a), (b) 1-methyl-3-(3,7,11,15-tetramethylhexadecyl)benzene (phytanyl toluene, 4b) and (c) 2-(3,7,11,15 tetramethylhexadecyl)naphthalene (phytanyl naphthalene, $\mathbf{4 c}$ ).

toluene/phytanyl benzene ratio ranges from 12.5 to 36.7 (based on integration of the $m / z 92$ and 106 chromatograms).
To illustrate the presence of phytanyl benzene and phytanyl toluene through the core the ratio of each compound relative to phenanthrene is shown in Fig. 4 (based on integration of the $m / z$ 92 and 106 relative to 178 chromatograms). Phenanthrene is present in all samples analysed but can be associated with variation in source (e.g. terpenoids or pyrolytic compounds), however, concentration does not change significantly in Hovea-3, suggesting no major source change. Phenanthrene was therefore chosen as the most suitable PAH to show the appearance of the phytanyl arenes. Although phytanyl benzene and phytanyl toluene appear suddenly and synchronously immediately above the local extinction/PTB horizon, maximum abundance does not occur until $11 \mathrm{~m}$ higher in the section (Fig. 5). In comparison, the peak abundance of $\mathrm{C}_{33}$ $n$-ACH identified in the same section by Grice et al. (2005b) occurs immediately after the local extinction/PTB horizon.

\subsubsection{Fiskegrav section}

Of the eleven samples, phytanyl toluene was present in seven and phytanyl benzene in four (Fig. 6). As in the Hovea-3 core, where the two co-occur, phytanyl toluene is present in greater relative abundance than phytanyl benzene. The maximum abundance of the two biomarkers occurs ca. $6.4 \mathrm{~m}$ above the local extinction horizon (i.e. "marine ecosystem collapse" of Twitchett et al., 2001); Fig. 6) but low abundance occurs just above the marine collapse. The maximum abundance of the two occurs during a macrofaunal "dead zone" that extends from the level of marine collapse until $14 \mathrm{~m}$ above the base of the Wordie Creek Formation, characterised by the total absence of bioturbation and benthic macrofossils and inferred to be the result of benthic anoxia (Looy et al., 2001; Twitchett et al., 2001). Even after the reappearance of benthic macrofossils (i.e. the bivalve Claraia), phytanyl toluene and phytanyl benzene remain absent until just above the first appearance of $H$. parvus. Biomarker relative abundance remains low vs. samples from shortly after the marine ecosystem collapse. $C_{33} n$ $\mathrm{ACH}$ appears with the onset of the marine collapse (Grice et al., 2005b), preceding the first occurrence of phytanyl toluene and phytanyl benzene, but is similarly absent throughout the remaining "dead zone", before reappearing above the first appearance of H. parvus.

\subsubsection{Spitsbergen section}

Phytanyl toluene was present in seven and phytanyl benzene in five of the ten samples from the lower Vikinghøgda Formation. Similar to the other two sections, phytanyl toluene is present in much greater relative abundance than phytanyl benzene, as shown in Fig. $3 \mathrm{C}$ and $\mathrm{F}$ based on the extracted ion chromatograms. The maximum abundance of both occurs $4.3 \mathrm{~m}$ above the base of the Vikinghøgda Formation and ca. $2.7 \mathrm{~m}$ above the collapse of the marine ecosystem (Fig. 7), but low abundance occurs just above the ecosystem collapse. The shallowest sample analysed, of unequivocal basal Induan age, did not contain any phytanyl benzene or phytanyl toluene. $\mathrm{C}_{33} n$-ACH first appears after the onset of the marine transgression and anoxia, reaches maximum abundance following the marine collapse, and remains present throughout the entire sampled section. Similar to Hovea-3 and the East Greenland section the first appearance of $\mathrm{C}_{33} n-\mathrm{ACH}$ precedes the appearance of phytanyl benzene and phytanyl toluene.

\subsection{Origin and significance}

The biomarker distribution and trends from the sampled PTB sections show some similarities. In all three sections the abundance of phytanyl benzene correlates well with the abundance of phytanyl toluene (Fig. 8), suggesting similar origin/source or similar environmental conditions that allowed the source organism to flourish under stressed environmental conditions. Both com- 


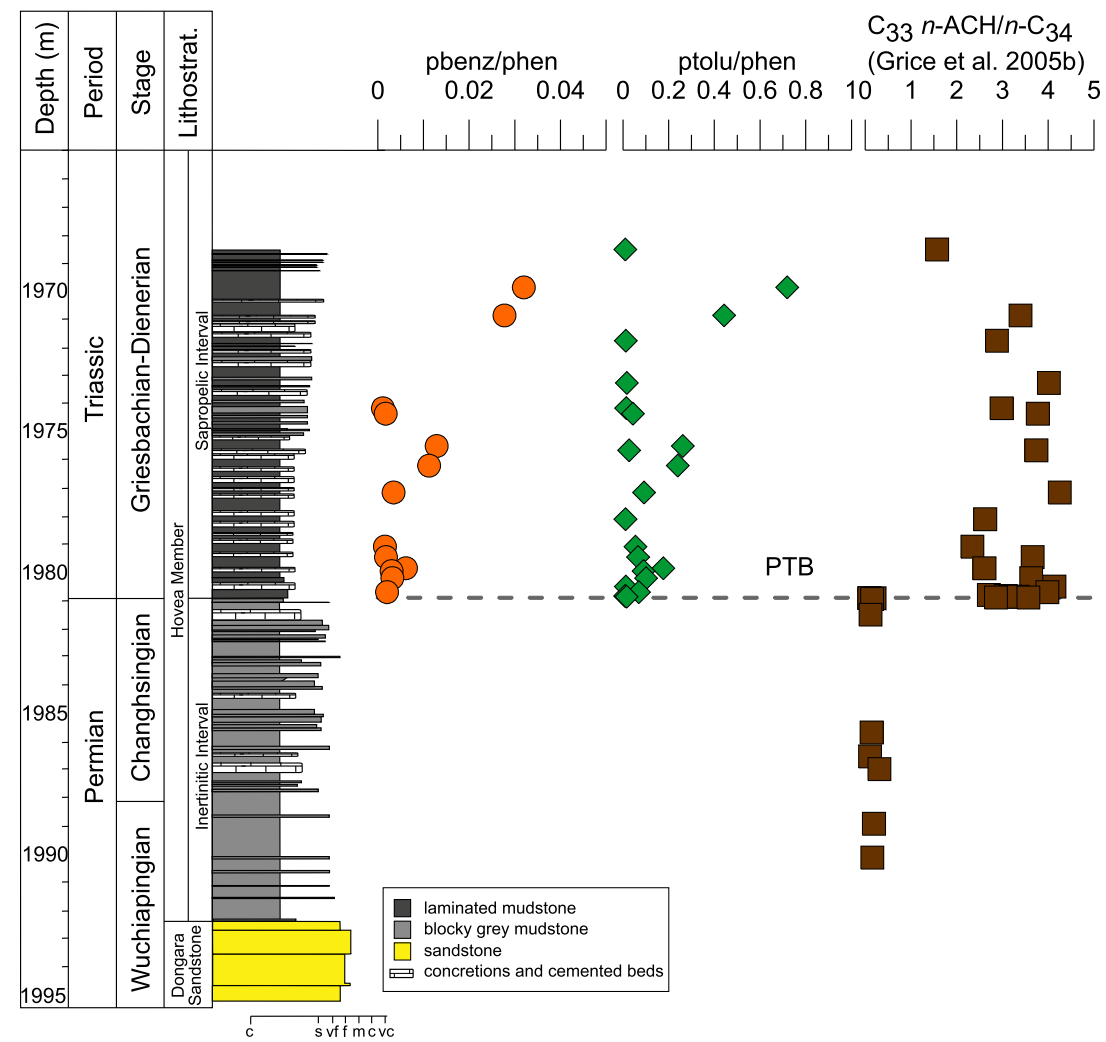

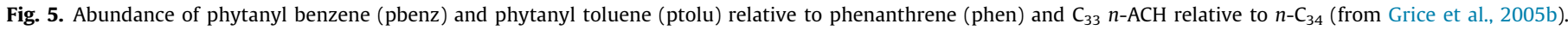

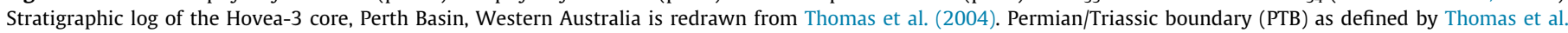
(2004). Lithological scale comprises claystone (c), siltstone (s), very fine- (vf), fine- (f), medium- (m), coarse-, and very coarse-grained sandstone (vc).

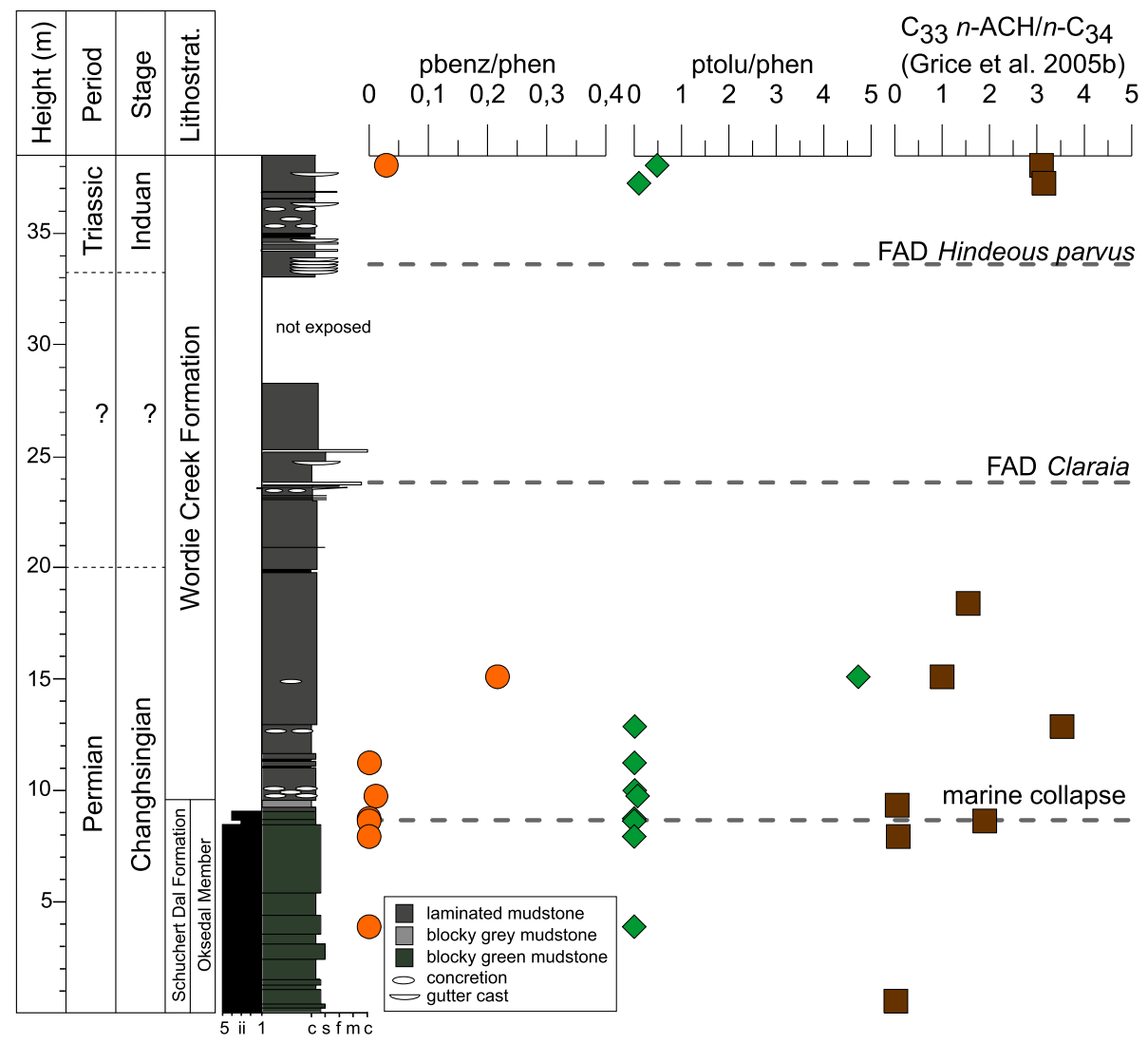

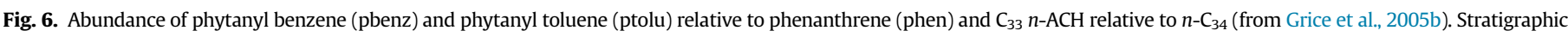

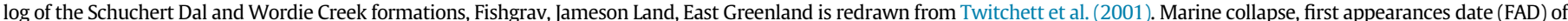

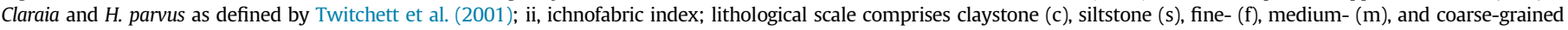
sandstone (c). Dashed horizontal lines and question marks indicate two alternative positions of the Permian/Triassic boundary (see Twitchett et al., 2001, for discussion). 


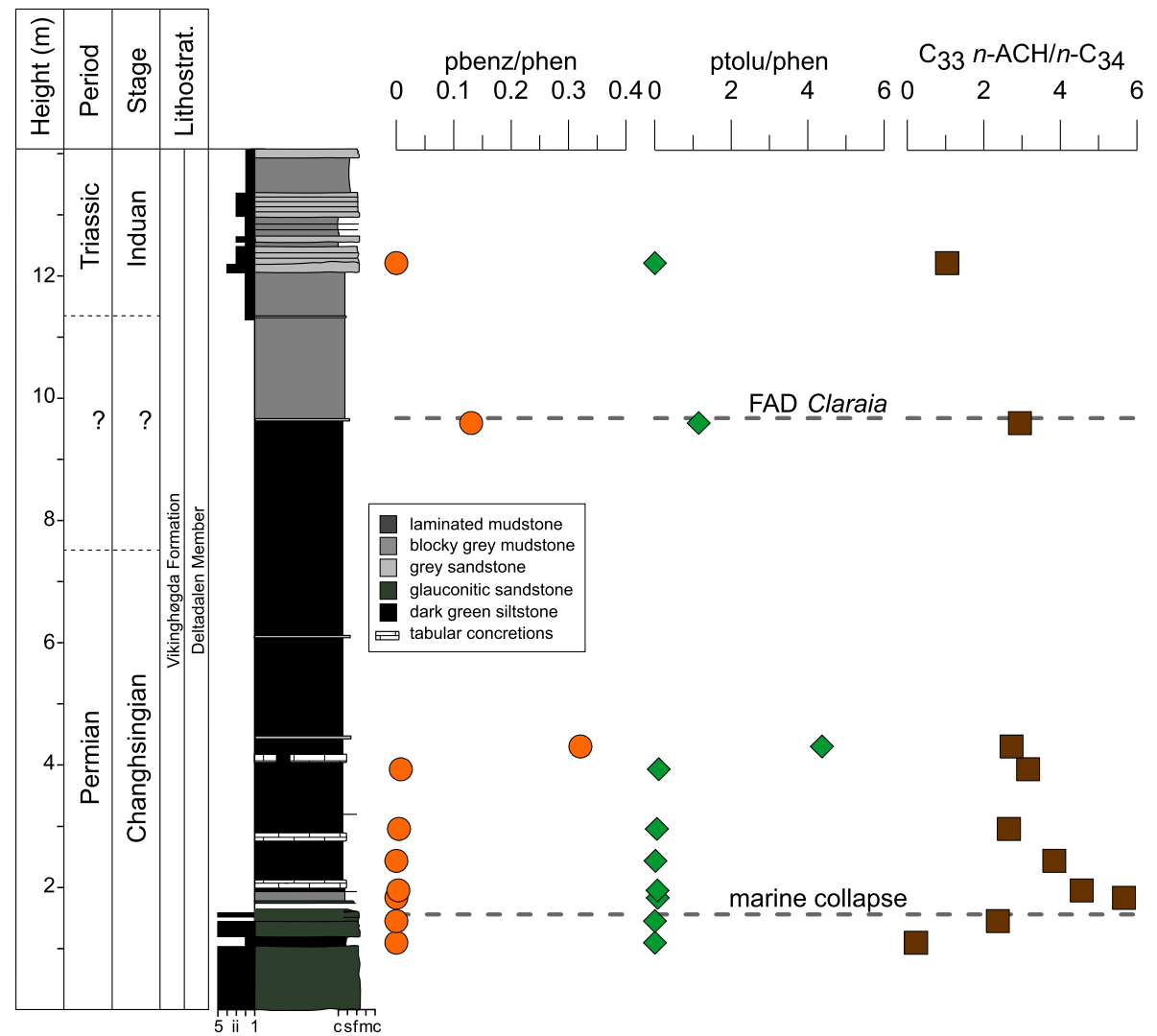

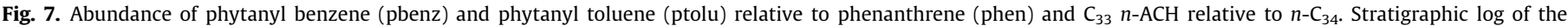

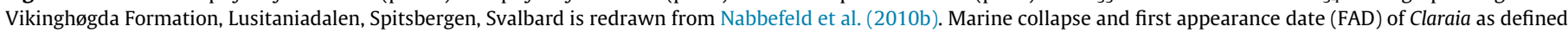

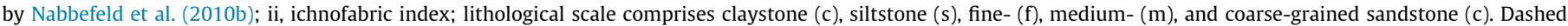
horizontal lines and question marks indicate two alternative positions of the Permian/Triassic boundary (see Nabbefeld et al., 2010b, for discussion).

pounds appear in low abundance shortly after the marine ecosystem collapse, with maximum abundance reached just above in East Greenland and Spitsbergen, and they almost vanish with the onset of the Triassic. In Western Australia, however, the compounds occur only above the palynologically-defined local PTB. The apparent hiatus in Hovea-3 makes a direct comparison with the other two sections difficult as the interval from the marine collapse to the PTB is not resolved and the extent of the missing record remains unclear.

The first appearance and maximum abundance of $\mathrm{C}_{33} n-\mathrm{ACH}$ precedes the first detection of phytanyl benzene and phytanyl toluene in all three sections and coincides with the onset of the marine ecosystem collapse in the PTB sections from Greenland and Spitsbergen. Although simultaneously elevated abundances of both groups of biomarkers are evident in all three sections, suggesting an origin from source organisms similarly adapted to environmental stress, $\mathrm{C}_{33} n$-ACH does not correlate with phytanyl toluene (Fig. 8).

The origin of ring-methylated phytanyl benzenes has not been determined. Sinninghe Damsté et al. (1988) suggested the formation of methylated phytanyl benzenes by diagenetic conversion of isoprenoid quinones. They also proposed a direct biosynthetic origin from specific archaea, halophilic ones living in hypersaline environments, and Sinninghe Damsté et al. (1993) showed the distribution of phytanyl benzene to be biologically controlled and palaeosalinity driven, at least in hypersaline environments. Although Nabbefeld et al. (2010b) have reported an increased concentration of the $C_{21}$ regular isoprenoid $\left(i-C_{21}\right)$ at the onset of the marine ecosystem collapse in the Spitsbergen section, its maximum abundance clearly precedes the maximum abundance of phytanyl toluene. The concentration declines immediately to precollapse levels (Nabbefeld et al., 2010b), indicating that any change in palaeosalinity, if it occurred at all, was only temporary and not related to the appearance of phytanyl toluene. This suggests here that, ring-methylated phytanyl benzenes do not originate from halophilic archaea.

The source of $\mathrm{C}_{33} n$-ACH has also not been positively identified. Nabbefeld et al. (2010b) supported the proposal of Grice et al. (2005b) that it might be a molecular marker for the Late Permian biotic crisis. Under this hypothesis, its source is proposed to be a post-event phytoplankton bloom that developed from the specific environmental conditions that triggered marine collapse and continued afterwards, such as global warming, sea level rise, spreading hypoxia, elevated run-off and flux of terrestrially-derived nutrients to shallow shelf seas (Grice et al., 2005b; Nabbefeld et al., 2010b).

The lack of a positive correlation between the abundance of $\mathrm{C}_{33}$ $n-\mathrm{ACH}$ and phytanyl toluene in any of the three PTB sections (Fig. 8) indicates that these biomarkers do not originate from the same source, but are from organisms that could live under stressed conditions. In the Spitsbergen and East Greenland PTB sections, the ring-methylated phytanyl benzene occurs after the maximum abundance of $\mathrm{C}_{33} \mathrm{n}-\mathrm{ACH}$ (Figs. 5-7). Hence, it is possible that environmental conditions that followed, or were created by, those that stimulated the phytoplankton bloom that generated the $\mathrm{C}_{33} n-\mathrm{ACH}$, provided ideal conditions for the appearance of a specific group of organisms that produced the ring-methylated phytanyl toluene.

Thus far, the three sections are the formations known to yield phytanyl benzene, phytanyl toluene and $\mathrm{C}_{33} n-\mathrm{ACH}$. Samples from the carbonate-dominated lithofacies of the Global Stratotype Section and Point (GSSP) at Meishan, South China, located near the 

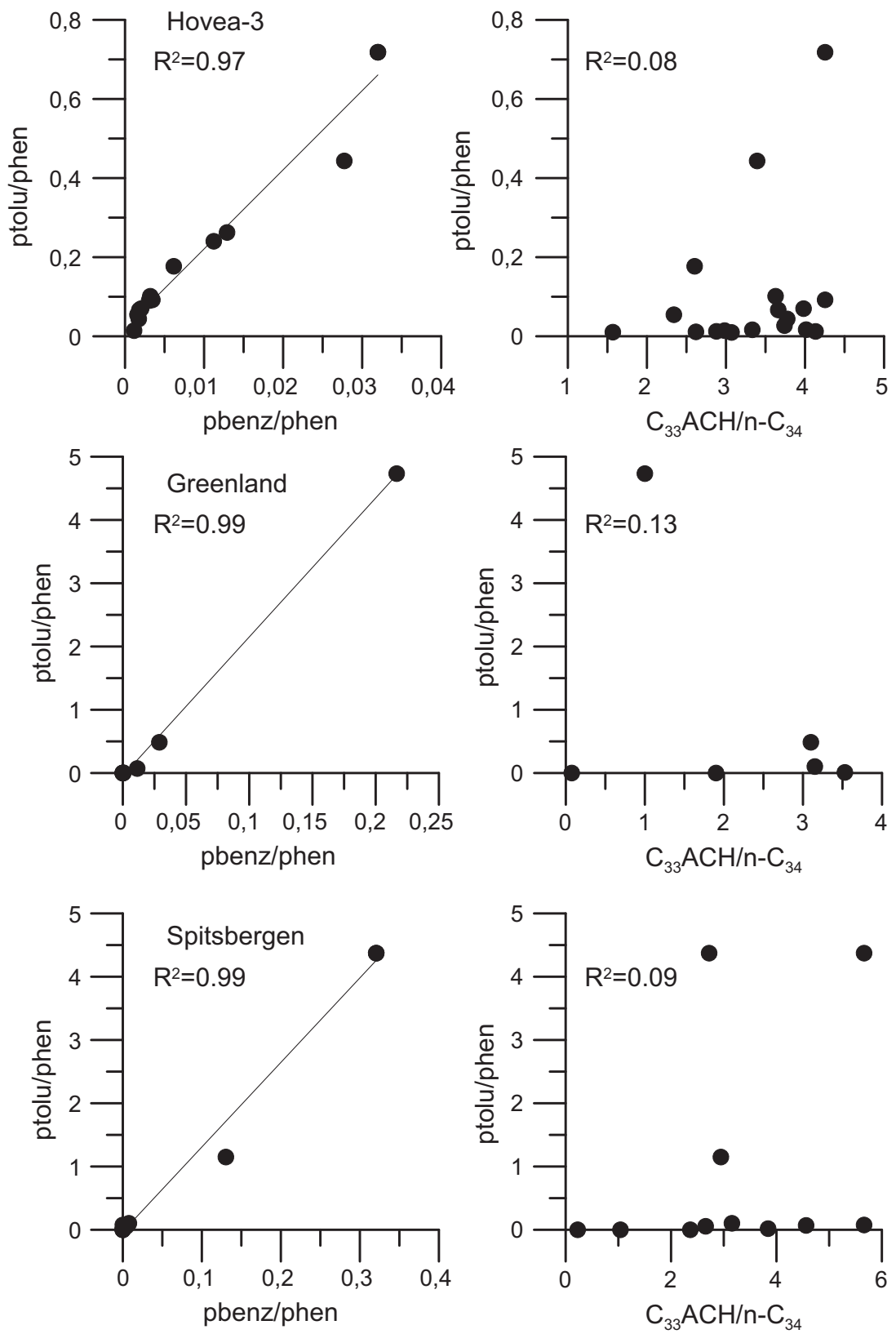

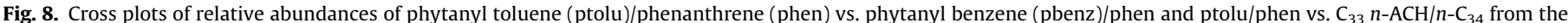
three sections from depths above the marine collapse.

equator during the Late Permian (Fig. 1), have been specifically investigated but did not yield any trace of phytanyl benzene, phytanyl toluene or $\mathrm{C}_{33} \mathrm{n}$ - $\mathrm{ACH}$. Marked lithological differences exist between the mid-latitudinal shale deposits and the equatorial carbonate deposit in Meishan, so differences in biomarker abundance could be related to preferential preservation of these compounds in siliclastic mudrocks compared with carbonates. Selective preservation can occur if the site dependent depositional conditions (e.g. redox conditions) or diagenetic/catagenetic reactions (e.g. acid or transition metal catalysis) promote biomarker decomposition. Preferential preservation cannot easily be proven or rejected and usually requires biomarker-specific laboratory simulations and hence remains a possibility in this case. However, general biomarker preservation appears to be favoured in carbonates than in shales (French et al., 2015). French et al. (2015) found significantly higher abundance of biomarkers in Archean carbonates than in shales of similar age. Further post-depositional catalytic reactions, e.g. acid or transition metal catalysis have been shown to occur primarily in shales and would not affect acidic mineral-free carbonates (Mango, 1990, 1992; Mango et al., 1994).

Based on current data, the global record of phytanyl benzene, phytanyl toluene and $\mathrm{C}_{33} n$-ACH shows an apparent latitudinal distribution, suggesting that the community of phytoplankton/organisms responsible for their occurrence may have been climate and/ or temperature controlled. If so, then we predict that they should be present in PTB samples from other locations that record marine deposition in mid-palaeolatitudes.

\section{Conclusions}

Phytanyl benzene and phytanyl toluene were identified in mudstones from several key Permian-Triassic Boundary (PTB) sections 
from mid-northern palaeolatitudes and mid-southern palaeolatitudes. The occurrence of these compounds is related to the occurrence of the previously identified $C_{33} n$-alkyl cyclohexane, suggesting they share a similar unique ecological niche and are associated with the extinction horizon. Their absence from the palaeoequatorial, GSSP, Meishan-1 (South China) of carbonate lithology possibly points to their origin to be further controlled by local temperature and climate.

\section{Acknowledgements}

The study was conducted by the Australian Research Council (ARC) and Discovery Outstanding Research Award project (KG DP130100577) and ARC LIEFP (LE110100119). H.G. thanks CSIRO and the Department of Chemistry, Curtin University, for a joint PhD scholarship as well as WA-OIGC for a part of the tuition fees and TIGeR for top-up scholarships. G. Chidlow is thanked for providing technical support for GC-MS. We thank the two anonymous reviewers for their helpful and constructive comments.

\section{Associate Editor-M. Elvert}

\section{References}

Albaigés, J., Algaba, J., Clavell, E., Grimalt, J., 1986. Petroleum geochemistry of the Tarragona Basin (Spanish mediterranean off-shore). Organic Geochemistry 10 441-450.

Benton, M.J., Twitchett, R.J., 2003. How to kill (almost) all life: the end-Permian extinction event. Trends in Ecology \& Evolution 18, 358-365.

Cassani, F., Gallango, O., Talukdar, S., Vallejos, C., Ehrmann, U., 1988 Methylphenanthrene maturity index of marine source rock extracts and crude oils from the Maracaibo Basin. Organic Geochemistry 13, 73-80.

Connan, J., Bouroullec, J., Dessort, D., Albrecht, P., 1986. The microbial input in carbonate-anhydrite facies of a sabkha palaeoenvironment from Guatemala: a molecular approach. Organic Geochemistry 10, 29-50.

Dawson, D. Grice, K., Alexander, R. 2005. Effect of maturation on the indigenous $\delta$ D signatures of individual hydrocarbons in sediments and crude oils from the Perth Basin (Western Australia). Organic Geochemistry 36, 95-104.

Dong, J.-Z., Vorkink, W.P., Lee, M.L., 1993. Origin of long-chain alkylcyclohexanes and alkylbenzenes in a coal-bed wax. Geochimica et Cosmochimica Acta 57, 837-849.

Ellis, L., Fisher, S.J., Singh, R.K., Alexander, R., Kagi, R.I., 1999. Identification of alkenylbenzenes in pyrolyzates using GC-MS and GC-FTIR techniques: evidence for kerogen aromatic moieties with various binding sites. Organic Geochemistry 30, 651-665.

Ellis, L., Singh, R.K., Alexander, R., Kagi, R.I., 1995. Geosynthesis of organic compounds: III. Formation of alkyltoluenes and alkylxylenes in sediments. Geochimica et Cosmochimica Acta 59, 5133-5140.

Fenton, S., Grice, K., Twitchett, R., Bottcher, M., Looy, C., Nabbefeld, B., 2007. Changes in biomarker abundances and sulfur isotopes of pyrite across the PermianTriassic (P/Tr) Schuchert Dal section (East Greenland). Earth and Planetary Science Letters 262, 230-239.

Foster, W.J., Twitchett, R.J., 2014. Functional diversity of marine ecosystems after the Late Permian mass extinction event. Nature Geoscience 7, 233-238.

French, K.L., Hallmann, C., Hope, J.M., Schoon, P.L., Zumberge, J.A., Hoshino, Y., Peters, C.A., George, S.C., Love, G.D., Brocks, J.J., Buick, R., Summons, R.E., 2015. Reappraisal of hydrocarbon biomarkers in Archean rocks. Proceedings of the National Academy of Sciences USA 112, 5915-5920. http://dx.doi.org/10.1073 pnas.1419563112.

Gallegos, E.J., 1981. Alkylbenzenes derived from carotenes in coals by GC/MS Journal of Chromatographic Science 19, 177-182.

Gandy, M.N., Piggott, M.J., 2008. Synthesis of kalasinamide, a putative plant defense phototoxin. Journal of Natural Products 71, 866-868.

Greenwood, P.F., Lengkeek, N.A., Piggott, M.J., Pierce, K., 2009. Structura identification and mass spectral interpretation of $C_{3 n}$ highly branched alkanes in sediment and aquatic extracts and evidence for their anthropogenic origin. Organic Geochemistry 40, 1055-1062.

Grice, K., Cao, C., Love, G.D., Böttcher, M.E., Twitchett, R.J., Grosjean, E., Summons, R. E., Turgeon, S.C., Dunning, W., Jin, Y., 2005a. Photic zone euxinia during the Permian-triassic superanoxic event. Science 307, 706-709.

Grice, K., Nabbefeld, B., Maslen, E., 2007. Source and significance of selected polycyclic aromatic hydrocarbons in sediments (Hovea-3 well, Perth Basin, Western Australia) spanning the Permian-Triassic boundary. Organic Geochemistry 38, 1795-1803.

Grice, K., Twitchett, R.J., Alexander, R., Foster, C.B., Looy, C., 2005b. A potential biomarker for the Permian-Triassic ecological crisis. Earth and Planetary Science Letters 236, 315-321.
Grimalt, J.O., Grifoll, M., Solanas, A.M., Albaiges, J., 1991. Microbial degradation of marine evaporitic crude oils. Geochimica et Cosmochimica Acta 55, 1903-1913.

Hartgers, W.A., Sinninghe Damsté, J.S., de Leeuw, J.W., 1994. Geochemical significance of alkylbenzene distributions in flash pyrolysates of kerogens, coals and asphaltenes. Geochimica et Cosmochimica Acta 58, 1759-1775.

Hays, L.E., Beatty, T., Henderson, C.M., Love, G.D., Summons, R.E., 2007. Evidence for photic zone euxinia through the end-Permian mass extinction in the Panthalassic Ocean (Peace River Basin, Western Canada). Palaeoworld 16, 3950.

Holzer, G., Oro, J., Tornabene, T.G., 1979. Gas chromatographic-mass spectrometric analysis of neutral lipids from methanogenic and thermoacidophilic bacteria. Journal of Chromatography 186, 795-809.

Hounslow, M.W., Peters, C., Mørk, A., Weitschat, W., Vigran, J.O., 2008. Biomagnetostratigraphy of the Vikinghøgda formation, Svalbard (Arctic Norway), and the geomagnetic polarity timescale for the lower Triassic. Bulletin of the Geological Society of America 120, 1305-1325.

Hübscher, J., Barner, R., 1990. Totalsynthese von natülichem $\alpha$-tocopherol. 5. Mitteilung. Asymmetrische alkylierung und asymmetrische epoxidierung als methoden zur einführung der (R)-konfiguration an C(2) des chroman-systems. Helvetica Chimica Acta 73, 1068-1086.

Killops, S., Stoddart, D., Mills, N., 2014. Inferences for sources of oils from the Norwegian Barents Sea using statistical analysis of biomarkers. Organic Geochemistry 76, 157-166.

Knierzinger, A., Walther, W., Weber, B., Müller, R.K., Netscher, T., 1990. Eine neue methode zur stereochemischen analyse offenkettiger terpenoider carbonylverbindungen. Helvetica Chimica Acta 73, 1087-1107.

Kulkarni, S.N., Phadke, A.S., Rangaishenvi, M.V., Kamath, S.V., 1988. Synthesis of phytol isomers - 7,11,15-trimethyl-3-methylenehexadecanol and 3,7,11,15tetramethylhexadec-3-en-1-ol and their conversion into vitamin-E. Indian Journal of Chemistry Section B-Organic Chemistry Including Medicinal Chemistry 27, 65-66.

Lengkeek, N.A., Greenwood, P.F., Nguyen, B., Koutsantonis, G.A., Piggott, M.J., 2010. Making mixtures to solve structures: structural elucidation via combinatorial synthesis. Journal of Combinatorial Chemistry 12, 141-150.

Looy, C.V., Twitchett, R.J., Dilcher, D.L., Van Konijnenburg-Van Cittert, J.H., Visscher, H., 2001. Life in the end-Permian dead zone. Proceedings of the National Academy of Sciences USA 98, 7879-7883.

Mango, F.D., 1990. The origin of light hydrocarbons in petroleum: a kinetic test of the steady-state catalytic hypothesis. Geochimica et Cosmochimica Acta 54, 1315-1323. http://dx.doi.org/10.1016/0016-7037(90)90156-F.

Mango, F.D., 1992. Transition metal catalysis in the generation of petroleum and natural gas. Geochimica et Cosmochimica Acta, 553-555.

Mango, F.D., Hightower, J.W., James, A.T., 1994. Role of transition-metal catalysis in the formation of natural gas. Nature 368, 536-538. http://dx.doi.org/10.1038/ $368536 \mathrm{a} 0$.

Mclldowie, M., Alexander, R., 2005. Identification of a novel $C_{33}$ n-alkylcyclohexane biomarker in Permian-Triassic sediments. Organic Geochemistry 36, 14541458.

Mørk, A., Elvebakk, G., Forsberg, A.W., Hounslow, M.W., Vigran, J.O., Weitschat, W., 1999. The Vikinghogda Formation - a new Lower Triassic type section for Central and Eastern Svalbard. Polar Research 18, 51-82.

Nabbefeld, B., Grice, K., Schimmelmann, A., Summons, R.E., Troitzsch, U., Twitchett, R.J., 2010a. A comparison of thermal maturity parameters between freely extracted hydrocarbons (Bitumen I) and a second extract (Bitumen II) from within the kerogen matrix of Permian and Triassic sedimentary rocks. Organic Geochemistry 41, 78-87.

Nabbefeld, B., Grice, K., Twitchett, R.J., Summons, R.E., Hays, L., Böttcher, M.E., Asif, M., 2010b. An integrated biomarker, isotopic and palaeoenvironmental study through the Late Permian event at Lusitaniadalen, Spitsbergen. Earth and Planetary Science Letters 291, 84-96.

Nakrem, H.A., Orchard, M.J., Weitschat, W., Hounslow, M.W., Beatty, T.W., Mørk, A., 2008. Triassic conodonts from Svalbard and their Boreal correlations. Polar Research 27, 523-539. http://dx.doi.org/10.1111/j.1751-8369.2008.00076.x.

Radke, M., Willsch, H., 1993. Generation of alkylbenzenes and benzo[b]thiophenes by artificial maturation of sulfur-rich coal. Fuel 72, 1103-1108.

Ryall, R.P., Nandi, D.L., Silverman, R.B., 1990. Substituted vitamin K epoxide analogues. New competitive inhibitors and substrates of vitamin K1 epoxide reductase. Journal of Medicinal Chemistry 33, 1790-1797.

Schaeflé, J., Ludwig, B., Albrecht, P., Ourisson, G., 1977. Hydrocarbures aromatiques d'origine geologique. II. Nouveaux carotanoïdes aromatiques fossiles. Tetrahedron Letters 18, 3673-3676.

Sinninghe Damsté, J.S., Keely, B.J., Betts, S.E., Baas, M., Maxwell, J.R., de Leeuw, J.W., 1993. Variations in abundances and distributions of isoprenoid chromans and long-chain alkylbenzenes in sediments of the Mulhouse Basin: a molecular sedimentary record of palaeosalinity. Organic Geochemistry 20, 1201-1215.

Sinninghe Damsté, J.S., Kock-van Dalen, A.C., de Leeuw, J.W., 1988. Identification of long-chain isoprenoid alkylbenzenes in sediments and crude oils. Geochimica et Cosmochimica Acta 52, 2671-2677.

Solli, H., Larter, S.R., Douglas, A.G., 1980. Analysis of kerogens by pyrolysis-gas chromatography-mass spectrometry using selective ion monitoring. III. Longchain alkylbenzenes. Physics and Chemistry of the Earth 12, 591-597.

Stemmerik, L., Bendix-Almgreen, S.E., Piasecki, S., 2001. The Permian-Triassic boundary in central East Greenland: past and present views. Bulletin of the Geological Society of Denmark 48, 159-167. 
Summons, R.E., Powell, T.G., 1987. Identification of aryl isoprenoids in source rocks and crude oils: biological markers for the green sulphur bacteria. Geochimica et Cosmochimica Acta 51, 557-566.

Thomas, B.M., Willink, R.J., Grice, K., Twitchett, R.J., Purcell, R.R., Archbold, N.W., George, A.D., Tye, S., Alexander, R., Foster, C.B., Barber, C.J., 2004. Unique marine Permian-Triassic boundary section from Western Australia. Australian Journal of Earth Sciences 51, 423-430.

Twitchett, R.J., Looy, C.V., Morante, R., Visscher, H., Wignall, P.B., 2001. Rapid and synchronous collapse of marine and terrestrial ecosystems during the endPermian biotic crisis. Geology 29, 351-354.
Upadhyay, H.C., Dwivedi, G.R., Roy, S., Sharma, A., Darokar, M.P., Srivastava, S.K. 2014. Phytol derivatives as drug resistance reversal agents. ChemMedChem 9 $1860-1868$.

Williams, J.A., Dolcater, D.L., Torkelson, B.E., Winters, J.C., 1988. Anomalous concentrations of specific alkylaromatic and alkylcycloparaffin components in west Texas and Michigan basin crude Oils. Organic Geochemistry 13, 47-60.

Yin, H.F., Zhang, K.X., Tong, J.N., Yang, Z.Y., Wu, S.B., 2001. The Global Stratotype Section and Point (GSSP) of the Permian-Triassic Boundary. Episodes 24, 102 114. 